\title{
A Perspective on Postharvest Horticulture (1978-2003)
}

\author{
Adel A. Kader \\ Department of Pomology, University of California, One Shields Avenue, Davis, CA 95616
}

\begin{abstract}
The goals of postharvest research and extension are to maintain quality and safety and minimize losses of horticultural crops and their products between production and consumption. Reduction of postharvest losses increases food availability to the growing human population, decreases the area needed for production, and conserves natural resources. Strategies for loss prevention include use of genotypes that have longer postharvest life, use of an integrated crop management system that results in good keeping quality, and use of proper postharvest handling systems that maintain quality and safety of the products. Thus, most horticulturists are involved to some extent in some aspects of postharvest horticulture, at least as consumers desiring fruit and vegetables with good flavor and nutritional quality and ornamentals with attractive appearance and long postproduction life.
\end{abstract}

Most accomplishments of postharvest horticulture have resulted from interdisciplinary, collaborative efforts among horticulturists and other plant biologists working with food scientists and engineers, marketing economists, consumer scientists, and other researchers and extensionists. Interactions among postharvest horticulturists and their colleagues from other disciplines are facilitated through the American Society for Horticultural Science (ASHS) Postharvest Working Group and the International Society for Horticultural Science (ISHS) Commission on Quality and Postharvest Horticulture.Also, many postharvest horticulturists participate regularly in ISHS International Postharvest Conferences, the Gordon Research Conferences on Postharvest Physiology, and the International Controlled Atmosphere Research Conferences, which have been held every 4 years since 1969. The Australasian Postharvest Conferences are held every 2 years in Australia or New Zealand. Results of postharvest research have been published in ASHS journals beginning with volume 9 of the Proceedings of the American Society for Horticultural Science published in 1913, as well as in a wide range of plant science, food science and technology, agricultural engineering, and other journals. Aspecialized abstracting journal titled Postharvest News and Information was initiated in 1990 and has been published bimonthly by CAB International. In 1991, Elsveir Science Ltd. initiated the journal Postharvest Biology and Technology, which has grown steadily (under the leadership of G.E. Hobson, R.P. Cavalieri, and I.B. Ferguson) in its ranking among journals and in frequency of publication to a monthly schedule in 2003. Published information covers the continuum from postharvest biology to technology of a broad range of horticultural crops and their products.

When ASHS celebrated its 75th anniversary in 1978, Professor Don Dewey, Michigan State University, reviewed the accomplishments of postharvest horticulture since 1903 under the title "Three Remarkable Generations of Postharvest Horticulture" (Dewey, 1979). Interest in postharvest horticulture within ASHS began early and expanded quickly as evidenced by the number of papers focused on postharvest physiology and quality that were published in the ASHS Proceedings. He reviewed the history of identifying ethylene as a gas that influences plant growth and development, fruit ripening, and senescence of harvested plant organs. He predicted correctly that "there seems little doubt but that ethylene will play a major role in our future work and publications." He also identified postharvest disorders (physiological and pathological) as an important research area that received much attention from postharvest horticulturists between 1903 and 1978. Identifying preharvest and postharvest factors that influence incidence and severity of physiological disorders remained an active research area during the past 25 years (Ferguson et al., 1999; Hodges, 2003). Important discoveries have concerned the nature of chilling injury (Saltveit, 2000; Wang, 1990), the control of storage scald on apple, the cause of bent-neck in cut roses, and the role of calcium (Bangerth, 1979) or other elements in tomato blossom-end rot, tipburn in lettuce, and flesh breakdown in apple. However, in most cases the underlying molecular and physiological causes are yet to be discovered. Dewey (1979) concluded his presentation by challenging

E-mail aakader@ucdavis.edu. horticulturists to make postharvest research a more sophisticated and far reaching science than it was in 1978. In this presentation I will provide a brief review of developments in postharvest horticulture during the past 25 years which represent the fourth remarkable generation of postharvest horticulture.

\section{POSTHARVEST BIOLOGY}

Together, Kidd and West's discovery of the climacteric and Blackman's monumental studies of respiration in apples established the basis of modern postharvest physiology (Laties, 1995). Professor Jacob Biale and his students contributed greatly to the development of postharvest physiology research during the 1950s, 1960s, and beyond. Romani (1991), in an excellent feature article published in HortScience, provided his perspective on postharvest physiology and biochemistry during 4 decades (1950 to 1989) and future outlook for the 1990s. He concluded that "whatever its future directions, research in postharvest physiology and biochemistry promises to be an increasingly well-delineated field of scientific inquiry." Sharples (1990), King and O'Donoghue (1995), and Mattoo and Handa (2001) presented their perspectives of postharvest biology research.

Saltveit et al. (1998) reviewed the history of the discovery of ethylene as a plant growth substance, the identification of 1-aminocyclopropane1-carboxylic acid (ACC) as the precursor of ethylene by Adams and Yang (1979) and Lürssen et al. (1979), and the recognition of ACC synthase and ACC oxidase as key enzymes of ethylene biosynthesis. They concluded that "while great advances had been made with the traditional techniques of physiology and biochemistry, further elucidation of ethylene biosynthesis and action hinged on using the modern techniques of molecular biology and genetic engineering."Breakthroughs in understanding ethylene signal transduction came from pursuing a genetic approach in Arabidopsis thaliana (Bleeker, 1999). A family of ETR1-like receptors interact with CTR 1 to express ethylene response pathways while ethylene binding inhibits this activity. Asummary of factors that influence ethylene biosynthesis and action is presented in Fig. 1.

Molecular and genetic analysis of fruit development, and especially ripening of fleshy fruit, has resulted in significant gains in knowledge over recent years about ethylene biosynthesis and response, cell wall metabolism, and environmental factors that impact ripening (Grierson, 1987; Seymour et al., 1993; Giovannoni, 2001). The isolation of fruit ripening-related genes has resulted not only in tools for studying the direct effects of specific gene products on ripening but also in opportunities to isolate and study gene regulatory elements that may illuminate regulatory mechanisms (Giovannoni, 2001).

Biotechnology is a tool that can be used, in an interdisciplinary approach, to address some of the concerns about quality attributes and

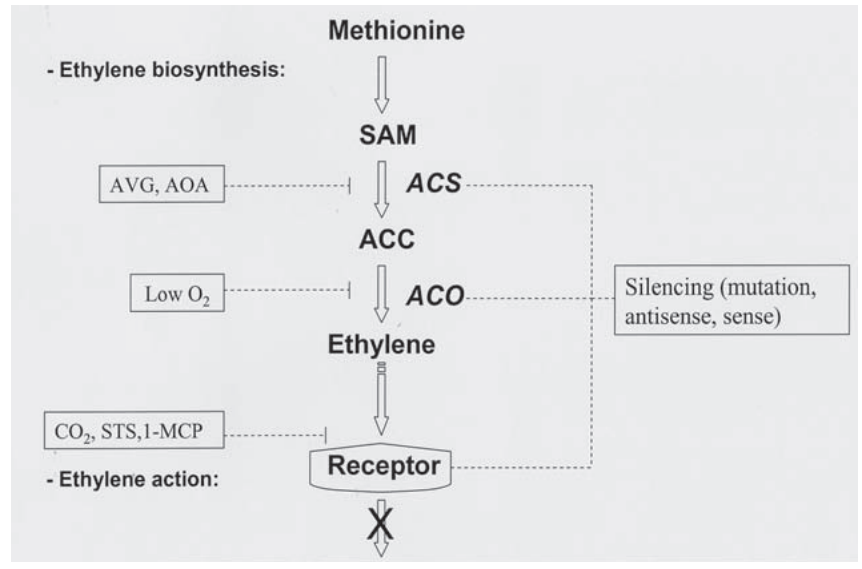

Fig. 1. A summary of factors that influence ethylene biosynthesis and action (courtesy of Bruno Defilippi). 
the biological causes of deterioration of harvested produce (King and O'Donoghue, 1995; Mattoo and Handa, 2001). Kader (2002b) proposed that priority should be given to the following goals: 1) to attain and maintain good flavor and nutritional quality to meet consumer demands and encourage greater consumption of fresh fruit and vegetables, 2) to introduce resistance to physiological disorders and/or decay-causing pathogens to reduce use of chemicals, and 3) to modify surface structure and/or composition of some commodities to reduce their microbial contamination potential.

The challenge to molecular biologists is that many of the desired improvements require manipulation of more than one gene, and in some cases target genes have not yet been identified.

Oxidative stress occurs when the generation of active oxygen species (e.g., $\mathrm{H}_{2} \mathrm{O}_{2}$ and $-\mathrm{OH}$ ) exceeds the capacity of the organism to maintain redox homeostasis and results in physiological disorders (Hodges, 2003.). Antioxidants that protect plant products against stress also play an important role in protecting humans against heart disease, cancer, and other chronic and degenerative diseases (Hyson, 2002; Prior and Cao, 2000). Many postharvest researchers are involved in evaluating antioxidant activities and phytochemical constituents in various fruit and vegetables as affected by cultivar, production practices, and postharvest handling procedures (Buescher et al., 1999; Goldman et al., 1999; Kalt, 2001; Perkins-Veazie and Collins, 2001). This will likely continue to be an active research area in the future.

\section{POSTHARVEST TECHNOLOGY}

Research aimed at identifying maturity and quality indices for a broad range of horticultural crops was continued during the past 25 years. Many nondestructive methods of quality evaluation have been developed (Abbott et al., 1997). More attention is focused on flavor quality



Fig. 2. Actions needed to maintain the cold chain throughout the postharvest handling system for perishable horticultural crops.
(Mattheis and Fellman, 1999). Optimal postharvest handling conditions for more than 100 commodities were defined and published in a revised edition of USDA Handbook No. 66 (Hardenburg et al., 1986), which was recently revised again with contributions by 90 authors (Gross et al., 2002). Other books that provided relevant information on postharvest biology and technology of horticultural crops include those by Ryall and Lipton (1979), Ryall and Pentzer (1982), Kays (1991), Seymour et al. (1993), Shewfelt and Prussia (1993), Thompson (1996), Wills et al. (1998), Bartz and Brecht (2002), Knee (2002), Kader (2002a), and Kitinoja and Kader (2002).

Research on how to maintain quality and safety of fresh-cut fruit and vegetables increased greatly during the past 15 years in response to commercial development of value-added, ready-to-eat products. Strategies for delaying browning and softening of wounded plant tissues and for maintaining their safety by minimizing microbial growth have been developed (Gorny, 2002; Lamikanra, 2002), but more research is needed to enable extension of postcutting life based on flavor and nutritional quality.

Providing the optimal ranges of temperature and relative humidity $(\mathrm{RH})$ is the most important tool for maintaining quality and safety of intact and fresh-cut fruit and vegetables, fresh herbs, and ornamental crops (Cantwell and Reid, 1993; Gross et al., 2002; International Institute of Refrigeration, 1993 and 1995; Kader, 2002a; Nell and Reid, 2000; Thompson et al., 1998; Internet sites: http://postharvest.ucdavis.edu; http: //www.postharvest.com.au; www.fao.org/inpho). There is a continuing trend toward increased precision in temperature and relative humidity (RH) management to provide the optimum environment for fresh produce during cooling, storage, and transport. Precision temperature management tools, including time-temperature monitors, are becoming more common in cooling and storage facilities. Several manufacturers have developed self-contained temperature and RH monitors and recorders, which are small and can be packed in a box with the product. Data are read by connecting these units to a personal computer with the appropriate software provided by the manufacturer. Infrared thermometers are used to measure surface temperature of products from a distance in various locations within storage facilities. Electronic thermometers (with very thin, strong probes for fast response) are used for measuring product temperature during cooling, storage, and transport operations. Recent surveys indicate an improvement in temperature maintenance within refrigerated display cabinets used in retail stores with an overall mean of about $5^{\circ} \mathrm{C}$. There is no substitute to maintaining the cold chain throughout the postharvest handling system (Fig. 2) for ensuring quality and safety of horticultural perishables. All other postharvest technology procedures are supplements to proper temperature management (Fig.3).

Continued research on technologies to reduce water loss included use of polymeric films (Ben Yehoshua, 1985) and surface coatings (Amarante and Banks, 2001; Baldwin, 1994). The use of polymeric films for packaging produce and their application in modified atmosphere packaging (MAP) systems at the pallet, shipping container (plastic liner), and consumer

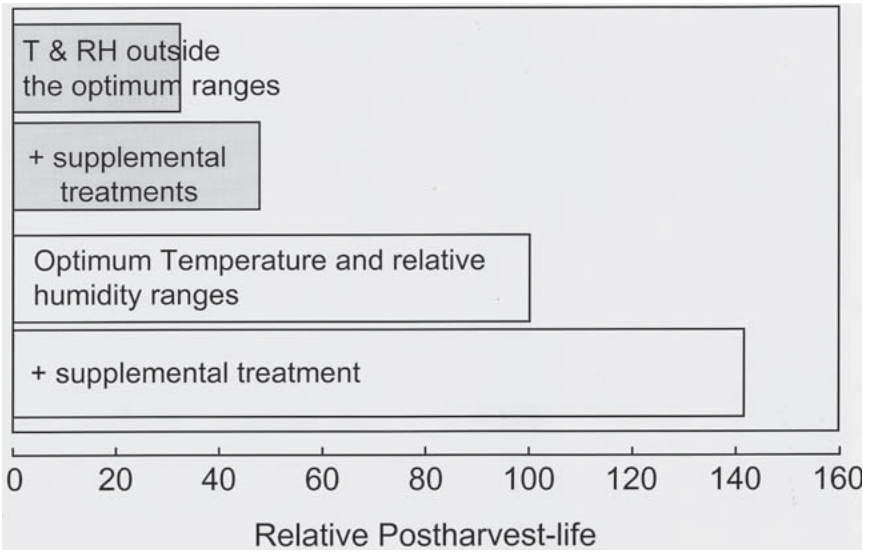

Fig. 3. Providing optimal ranges of temperature and relative humidity is the most effective method for extending postharvest life. All other technologies (such as waxing, postharvest fungicides, sprout inhibitors, controlled or modified atmospheres, ethylene exclusion or scrubbing, and 1-MCP treatments) are supplemental and extend postharvest life by only $25 \%$ to $40 \%$. 
package levels continues to increase (Beaudry, 2000; Kader et al., 1989; Lange, 2000; Watkins, 2000). MAP (usually to maintain $2 \%$ to $4 \% \mathrm{O}_{2}$ and $8 \%$ to $12 \% \mathrm{CO}_{2}$ ) is widely used in extending the shelf life of fresh-cut vegetable and fruit products. Use of absorbers of ethylene, carbon dioxide, oxygen, and/or water vapor as part of MAP is increasing. Although much research has been done on use of surface coatings to modify the internal atmosphere within the commodity, commercial applications are still very limited due to the variability of the commodity's gas diffusion characteristics and the stability and thickness of the coating.

Several refinements in CA storage technology have been made in recent years (Calderon and Barkai-Golan, 1990). These include the creation of nitrogen on demand by separation from compressed air using molecular sieve beds or membrane systems (Dilley, 1990), use of low $(0.7 \%$ to $1.5 \%) \mathrm{O}_{2}$ concentrations that can be accurately monitored and controlled, rapid establishment of CA, ethylene-free CA, programmed (or sequential) $\mathrm{CA}$ (such as storage in $1 \% \mathrm{O}_{2}$ for 2 to 6 weeks followed by storage in $2 \%$ to $3 \% \mathrm{O}_{2}$ for the remainder of the storage period), and dynamic $\mathrm{CA}$ where levels of $\mathrm{O}_{2}$ and $\mathrm{CO}_{2}$ are modified as needed based on monitoring some attributes or produce quality, such as ethanol concentration and chlorophyll fluorescence.

The use of CA in refrigerated marine containers continues to benefit from technological and scientific developments. CA transport is used to continue the CA chain for some commodities (such as apples, pears, and kiwifruit) that had been stored in CA since harvest. CA transport of bananas permits their harvest at a more fully mature stage resulting in higher yield. CA transport of avocados facilitates use of a lower temperature $\left(5^{\circ} \mathrm{C}\right)$ than if shipped in air because $\mathrm{CA}$ ameliorates chilling injury symptoms. CA combined with precision temperature management may allow nonchemical insect control in some commodities (Mitcham, 2003) for markets that have restrictions against pests endemic to exporting countries and for markets that prefer organic produce.

At the commercial level, CA is most widely applied during the storage and transport of apples and pears. It is also applied to a lesser extent on asparagus, broccoli, cantaloupes, kiwifruit, avocados, persimmons, pomegranates, and nuts and dried fruit. Atmospheric modification during transport is used on apples, avocados, bananas, blueberries, cherries, figs, kiwifruit, mangoes, nectarines, peaches, pears, plums, raspberries, and strawberries. Continued technological developments in the future to provide CA during transport and storage at reasonable cost (positive benefit-cost ratio) are essential to expanding its application on fresh fruit and vegetables.

The promotion of senescence in harvested horticultural crops by ethylene $(>0.1 \mathrm{ppm})$ results in acceleration of deterioration and reduced postharvest life. Ethylene accelerates chlorophyll degradation causing yellowing of green tissues, thus reducing quality of leafy, floral, and immature fruit and vegetables and foliage ornamentals. Ethylene induces abscission of leaves and flowers, softening of fruit, and several physiological disorders (Abeles et al., 1992; Reid, 1995). Ethylene may increase decay development of some fruit by accelerating their senescence and softening, and by inhibiting the formation of antifungal compounds in the host tissue. In some cases, ethylene may stimulate growth of fungi such as Botrytis cineria on strawberries and Penicillium italicum on oranges (Sommer, 1989).

Low temperatures, controlled or modified atmospheres (Kader, 1986a), treatment of ornamentals with silver thiosulfate, and ethylene avoidance and/or scrubbing techniques are used to reduce ethylene damage. The discovery of the ethylene action inhibitor, 1-methylcyclopropene (1-MCP), in the early 1990s (Sisler and Blankenship, 1996) is a major breakthrough. Since 1999, 1-MCP has been used under the trade name Ethylbloc for treatment of cut flowers and other ornamental crops to render them insensitive to ethylene action and associated detrimental effects. In July 2002, 1-MCP (under the trade name SmartFresh) at concentrations up to $1 \mathrm{ppm}$ was approved by the U.S. Environmental Protection Agency for use on apples, apricots, avocados, kiwifruit, mangoes, nectarines, papayas, peaches, pears, persimmons, plums, and tomatoes. The first commercial application has been on apples to retard their softening and scald development and extend their postharvest life. As more research is completed, the use of 1-MCP will no doubt be extended to several other commodities in the future (Blankenship and Dole, 2003).

Currently used treatments for decay control include 1) heat treatments (Lurie, 1998; Paull and Chen, 2000) such as dipping mangoes for $5 \mathrm{~min}$ in $50{ }^{\circ} \mathrm{C}$ water to reduce subsequent development of anthracnose; 2) use of postharvest fungicides such as imazalil and/or thiabendazole on citrus fruit; 3 ) use of biological control agents (Wilson and Wisniewski, 1989) such as bio-Save (Pseudomonas syringae) and Aspire (Candida olephila) alone or in combination with fungicides at lower concentrations on citrus fruit; 4) use of growth regulators such as gibberellic acid or 2, 4-D to delay senescence of citrus fruit; 5) use of $15 \%$ to $20 \% \mathrm{CO}_{2}$ in air or $5 \% \mathrm{O}_{2}$ on strawberries, cane berries, figs, and pomegranates; and 6) use of $\mathrm{SO}_{2}$ fumigation (100 ppm for $1 \mathrm{~h}$ ) on grapes.

A large number of insects can be carried by fresh fruit, vegetables, and flowers during postharvest handling. Many of these insect species, especially the fruit flies of the family Tephritidae (e.g., mediterranean fruit fly, oriental fruit fly, mexican fruit fly, caribbean fruit fly), can seriously disrupt trade among countries. Continuing globalization of marketing fresh produce will be facilitated by use of acceptable disinfestation treatments. Selection of the best treatment for each commodity will depend on the comparative cost and the efficacy of that treatment against the insects of concern with the least potential for damaging the host (Paull and Armstrong, 1994; Sharp and Hallman, 1994). Much of the research during the past 15 years has been focused on finding alternatives to methyl bromide fumigation.

Currently approved quarantine treatments include certification of insect-free areas, use of chemicals (e.g., methyl bromide, phosphine, hydrogen cyanide), cold treatments, heat treatments, irradiation, and some combinations of these treatments, such as methyl bromide fumigation followed by cold treatment. The potential for additional treatments, such as new fumigants (carbonyl sulfide, methyl iodide, sulfuryl fluoride), insecticidal atmospheres $\left(<0.5 \% \mathrm{O}_{2}\right.$ and/or $40 \%$ to $\left.60 \% \mathrm{CO}_{2}\right)$ alone on or in combination with heat treatments, and ultraviolet radiation, is being investigated. Each of these treatments is usable on a limited number of commodities but causes phytotoxic effects on others.

Most insects are sterilized when subjected to irradiation doses ranging between 50 and $750 \mathrm{~Gy}$. The actual dosage required varies in accordance with the species and its stage of development. An irradiation dose of 250 Gy has been approved for certain fresh commodities, such as lychees, mangoes, and papayas by U.S. quarantine authorities in light of its efficacy in preventing adult emergence of tropical fruit flies. Most fresh fruit and vegetables will tolerate irradiation dose of $250 \mathrm{~Gy}$ with minimal detrimental effects on quality. At doses above $250 \mathrm{~Gy}$ and up to $1000 \mathrm{~Gy}$ (the maximum allowed as of 2003), damage can be sustained by some commodities (Kader, 1986b). Fruit, in general, are more tolerant to the expected dose range ( 250 to 500 Gy absorbed by fruit on the inside vs. those on the outside of the pallet) than nonfruit vegetables and cut flowers. Detrimental effects on fresh produce may include loss of green color (yellowing), abscission of leaves and petals, tissue discoloration, and uneven ripening.

\section{FOOD SAFETY AND SECURITY}

Over the past few years, food safety has become and continues to be the number one concern of the fresh produce industry (Bracket, 1999; Kitinoja and Gorny, 1999). The U.S. Food and Drug Administration (USFDA) published in October 1998 a Guide to Minimize Microbial food Safety Hazards for Fresh Fruit and Vegetables. This guide is based on the general principle that prevention of microbial contamination of fresh produce is favored over reliance on corrective actions once contamination has occurred. A manual for trainers, titled Improving the Safety and Quality of Fresh Fruit and Vegetables, was published by the USFDA in November 2002 to provide uniform, broad-based scientific and practical information on the safe production, handling, storage, and transport of fresh produce. It is available electronically (in English and Spanish) at http://www.jifsan.umd.edu/gaps.html. Another useful website is the University of California's Good Agricultural Practices available at http: //ucgaps.ucdavis.edu.

Clean, disinfected water is required to minimize the potential transmission of pathogens from water to produce, from healthy to infected produce within a single lot, and from one lot to another over time. Waterborne microorganism, including postharvest plant pathogens and agents of human illness, can be rapidly acquired and taken up on plant surfaces. Natural plant surface contours, natural openings, harvest and trimming wounds, and scuffing can be points of entry as well as provide 
safe harbor for microbes. In these protected sites, microbes are largely unaffected by common or permitted doses of postharvest water sanitizing treatments (e.g., chlorine compounds, ozone, and hydrogen peroxide). It is essential therefore, that an adequate concentration of sanitizer is maintained in water to kill microbes before they attach or become internalized in product. This is important in some preharvest water uses (such as spraying pesticides or growth regulators) and in all postharvest procedures involving water, including washing, cooling, water-mediated transport (flumes), and postharvest drenching with calcium chloride or other chemicals.

The emphasis of current research on produce safety is on developing reliable and quick detection methods for human pathogens, improved efficacy of water disinfection methods, and developing methods for reducing microbial load on intact and fresh-cut fruit and vegetables. Other aspects of produce safety include assuring that the residues of pesticides are within the legal limits and handling conditions that may lead to contamination with mycotoxins are avoided.

The national organic standards in the U.S. became effective in October 2002 and are available electronically at http://www.ams.usda.gov/nop/. Organic produce must be handled separately from conventionally grown produce to avoid cross-contamination with pesticide residues. Water disinfection treatments, such as chlorination and ozonizations, can be used on organic produce to minimize the potential for microbial contamination.

On 19 Mar. 2003, The U.S. Food and Drug Administration (USFDA) released food security guidance documents for food producers, processors, and transporters. These documents are available electronically at http://www.cfsan.fda.gov/ dms/secguid6.html and are voluntary recommendations from USFDA - not mandatory regulations. The goal is to help operators of food handling facilities identify preventive measures to minimize the security risks to their products.

\section{THE VALUE OF POSTHARVEST RESEARCH AND EXTENSION}

Postharvest losses vary greatly among commodities and production areas and seasons. In the U.S., the losses of fresh fruit and vegetables are estimated to range from $2 \%$ to $23 \%$, depending on the commodity, with an overall average of about $12 \%$ losses between production and consumption sites (Cappellini and Ceponis, 1984; Harvey, 1978). Kantor et al. (1997) estimated the U.S. total retail, foodservice, and consumer food losses in 1995 to be $23 \%$ of fruit and $25 \%$ of vegetables. Fresh fruit and vegetables accounted for nearly $20 \%$ of consumer and foodservice losses, which are due to product deterioration, excess perishable products that are discarded, and plate waste (food not consumed by the purchaser). The latter is often due to consumer dissatisfaction with product quality, especially flavor. Estimates of postharvest losses in developing countries vary greatly from $1 \%$ to $50 \%$ or even higher (FAO, 1981; National Academy of Sciences, 1978). Mrema and Rolle (2002) reported that priorities within the postharvest sector of developing countries have evolved from a primarily technical focus geared toward the reduction of losses to a more holistic approach designed to link on-farm activities to processing, marketing, and distribution. Despite this evolution in trends, fundamental problems and concerns of the sector have remained relatively unchanged, with high postharvest losses, poor marketing systems, weak research and development capacity, and inadequacies in policies, infrastructure, and information exchange cited as major constraints within the sector in developing regions of the world (Mrema and Rolle, 2002). Similar conclusions were reached by the participants in a workshop on Postharvest Technologies for Developing Countries that was organized by Errol W. Hewett during the 26th International Horticultural Congress in Toronto, Canada (August 2002).

Although minimizing postharvest losses of already produced food is more sustainable than increasing production to compensate for these losses, less than $5 \%$ of the funding of agricultural research is allocated to postharvest research areas. This situation must be changed to increase the role of postharvest loss reduction in meeting world food needs. Goletti and Wolff (1999) stated that "while research on the improvement of agricultural production has received considerable attention and funding, until recently postharvest activities have not attracted much attention from international research organizations (CGIAR, FAO, ACIAR, IDRC, CTZ, CIRAD, NRI, USAID).” They identified the following reasons to justify
Based on flavor and nutritional quality

Based on firmness

Based on appearance (visual quality)

\begin{tabular}{cccccc}
\hline & 1 & 1 & & \\
\hline 0 & 20 & 40 & 60 & 80 & 100
\end{tabular}

Fig. 4. Postharvest life based on flavor and nutritional quality is shorter than postharvest life based on firmness of appearance of most fresh fruit and vegetables.

an increased commitment to postharvest research by the international agricultural system: 1) high internal rates of return, 2) international public good character, 3) effect on poverty, 4) effect on food security and health, and 5) effect on sustainable use of resources. Goletti and Wolff (1999) concluded that "As the significant contribution of postharvest research to CGIAR goals such as poverty reduction, food security and sustainability becomes clear, and in the light of high rates of return, the very skewed allocation of funds to production versus postharvest topics cannot be justified. Since, so far, relatively little has been invested in postharvest research, there is potential for large impacts as constraints and bottlenecks are removed. It would thus be desirable to re-examine current funding priorities and to allocate a larger proportion of resources to the postharvest area."

\section{FUTURE OUTLOOK}

Remarkable progress in postharvest biology and technology of horticultural crops has been achieved during the past 25 years through collaborative and interdisciplinary research and development efforts of the public and private sectors, especially in developed countries. Achieving similar progress in developing countries requires application of current knowledge to improve the handling systems of horticultural perishables and overcoming the socioeconomic constraints that have prevented such progress.

Devoting more attention to flavor and nutritional quality of fruit and vegetables is strongly recommended. This should include identification of the reasons for postharvest life based on flavor being shorter than postharvest life based on appearance (Fig. 4), selection of cultivars with flavor life that is close to appearance life, and modification of current postharvest handling recommendations based on maximizing flavor life potential.

New cultivars of fruit and vegetable with better flavor and nutritional quality will be developed using biotechnology and/or plant breeding methods. This will contribute to increased consumption and consequently healthier diets for consumers. Educational efforts such as those of the Produce for Better Health Foundation (www.5aday.org) and the National Cancer Institute (www.5aday.gov) must be expanded to achieve their goals.

Innovative technologies for maintaining optimal temperature and relative humidity, delaying losses of flavor and nutritional quality by supplemental treatments, and ensuring safety will continue to be developed through collaboration between public and private organizations.

Worldwide availability of both conventially and organically grown horticultural crops will continue to increase in terms of the number of species and cultivars as well as their expanded season of availability with production in northern and southern hemisphere countries. Continued consolidation and vertical integration among producers and marketers will characterize the global marketing systems for fresh produce. This will facilitate collaboration among producers and marketers from various production areas to limit the marketing period on the basis of availability of superior flavor quality products from each production area. Postharvest biologists and technologists will play a key role in shaping the future of postharvest horticulture as they have done in the past century. 


\section{Literature Cited}

Abbott, J.A., R. Lu, B.L. Upchurch, and R. Stroshine. 1997. Technologies for nondestructive quality evaluation of fruit and vegetables. Hort. Rev. 20:1-120.

Abeles, F.B., P. W. Morgan, and M.E. Saltveit. 1992. Ethylene in plant biology. 2nd ed. Academic Press, San Diego.

Adams, D.O. and S.F. Yang. 1979. Ethylene biosynthesis: identification of 1-aminocyclopropane-1-carboxylic acid as an intermediate in the conversion of methionine to ethylene. Proc. Nat. Acad. Sci. 76:170-174.

Amarante, C. and N.H. Banks. 2001. Postharvest physiology and quality of coated fruit and vegetables. Hort. Rev. 26:161-238.

Baldwin, E.A. 1994. Edible coatings for fresh fruit and vegetables: past, present, and future, p. 25-64. In: J.M. Krochta et al. (eds.). Edible coatings and films to improve food quality. Technomic Publ. Co., Lancaster, $\mathrm{Pa}$.

Bangerth, F. 1979. Calcium-related physiological disorders of plants. Annu. Rev. Phytopathol. 17:97-122.

Bartz, J.A. and J.K. Brecht (eds.). 2002. Postharvest physiology and pathology of vegetables 2nd ed. Marcel Dekker, New York.

Beaudry, R.M. 2000. Responses of horticultural commodities to low oxygen: limits to the expanded use of modified atmosphere packaging. HortTechnology 10:491-500.

Ben Yehoshua, S. 1985. Individual seal-packaging of fruit and vegetables in plastic film-a new postharvest technique. HortScience 20:32-38.

Blankenship, S.M. and J.M. Dole. 2003. 1-Methylcyclopropene: A review. Postharv. Biol. Technol. 28:1-25.

Bleeker,A.B. 1999. Ethylene perception and signaling: an evolutionary perspective. Trends Plant Sci. 4:269-274.

Brackett, R.E. 1999. Incidence, contributing factors, and control of bacterial pathogens in produce. Postharv. Biol. Technol. 15:305-311.

Buescher, R., L. Howard, and P. Dexter. 1999. Postharvest enhancement of fruit and vegetables for improved human health. HortScience 34:1167-1170

Calderon, M. and R. Barkai-Golan (eds.). 1990. Food preservation by modified atmospheres. CRC Press, Boca Raton, Fla.

Cantwell, M. and M.S. Reid. 1993. Postharvest physiology and handling of fresh culinary herbs. J. Herbs, Spices, Med. Plants 1(3):93-127.

Cappellini, R.A. and M.J. Ceponis. 1984. Postharvest losses in fresh fruit and vegetables, p. 24-30. In: H.E. Moline (ed.). Postharvest pathology of fruit and vegetables: Postharvest losses in perishable crops. Univ. Calif. Bul. 1914, Div. Agr. Nat. Resources, Oakland, Calif.

Dewey, D.H. 1979. Three remarkable generations of postharvest horticulture. HortScience 14:342-344.

Dilley, D.R. 1990. Historical aspects and perspectives of controlled atmosphere storage. $p$. 187-196, in: M. Calderon and R. Barkai-Golan (eds). Food preservation by modified atmospheres. CRC Press, Boca Raton, Fla.

Ferguson, I., R. Volz, and A. Woolf. 1999. Preharvest factors affecting physiological disorders of fruit. Postharv. Biol. Technol. 15:255-262.

Food and Agricultural Organization. 1981. Food loss prevention in perishable crops. U.N Food Agr. Org. Agr. Serv. Bul. 43.

Giovannoni, J. 2001. Molecular biology of fruit maturation and ripening. Annu. Rev. Plant Physiol. Plant Mol. Biol. 52:725-749.

Goldman, I.L., A.A. Kader, and C. Heintz. 1999. Influence of production, handling, and storage on phytonutrient content of foods. Nutr. Rev. 57(9): S46-S52.

Goletti, F. and C. Wolff. 1999. The impact of postharvest research. MSS Discussion Paper 29. Intl. Food Policy Res. Inst., Wash., D.C.

Gorny, J.R. (ed.). 2002. Food safety guidelines for the fresh-cut produce industry. 4th ed Intl. Fresh-cut Produce Assn., Alex., Va.

Grierson, D. 1987. Senescence in fruit. HortScience 22:859-862.

Gross, K., C.Y. Wang, and M.E. Saltveit (eds.). 2002. The commercial storage of fruit, vegetables, and florist and nursery stocks. USDA Agr. Hndbk. 66 (http: //www.ba.ars.usda.gov/hb66/index.html).

Hardenburg, R.E., A.E. Watada, and C.Y. Wang. 1986. The commercial storage of fruit, vegetables, and florist and nursery stocks. USDA Agr. Hndbk. 66.

Harvey, J.M. 1978. Reduction of losses in fresh market fruit and vegetables. Annu. Rev. Phytopathol. 16:321-341.

Hodges, D.M. (ed.). 2003. Postharvest oxidative stress in horticultural crops. Food Products Press, New York.

Hyson, D. 2002. The health benefits of fruit and vegetables. A scientific overview for health professionals. Produce for Better Health Found., Wilmington, Del.

International Institute of Refrigeration. 1993. Cold store guide. Intl. Inst. Refriger., Paris.

International Institute of Refrigeration. 1995. Guide to refrigerated transport. Intl. Inst. Refriger., Paris.

Kader,A.A. 1986a Biochemical and physiological basis for effects of controlled and modified atmospheres on fruit and vegetables. Food Technol. 40(5):99-100, 102-104.

Kader, A.A. 1986b. Potential applications of ionizing radiation in postharvest handing of fresh fruit and vegetables. Food Technol. 40(6):117-121.

Kader, A.A., D. Zagory, and E.L. Kerbel. 1989. Modified atmosphere packaging of fruit and vegetables. CRC Crit. Rev. Food Sci. Nutr. 28:1-30.

Kader, A.A. (ed.). 2002a. Postharvest technology of horticultural crops. 3rd ed. Univ. Calif Agr. Nat. Resources, Oakland, Publ. 3311.

Kader, A.A. 2002b. Opportunities in using biotechnology to maintain postharvest quality and safety of fresh produce. HortScience 37:467-468.

Kalt, W. 2001. Health functional phytochemicals of fruit. Hort. Rev. 27:269-315.

Kantor, L.S., K. Lipton, A. Manchester, and V. Oliveira. 1997. Estimating and addressing
America's food losses. Food Rev. 20:3-11

Kays, S.J. 1991. Postharvest physiology and handling of perishable plant products. van Nostrand Reinhold, New York.

King, G.A. and E.M. O’Donoghue. 1995. Unravelling senescence: new opportunities for delaying the inevitable in harvested fruit and vegetables. Trends Food Sci. Technol. 6:385-389.

Kitinoja, L. and J.R. Gorny. 1999. Postharvest technology for small-scale produce marketers: economic opportunities, quality and food safety. Univ. Calif., Davis, Posthar. Hort. Ser. 21.

Kitinoja, L. and A.A. Kader. 2002. Small-scale postharvest handling practices: a manual for horticultural crops. Fourth edition. Univ. Calif., Davis, Posthar. Hort. Ser. 8E.

Knee, M. (ed.). 2002. Fruit quality and its biological basis. Sheffield Academic Press, Sheffield, U.K

Lamikanra, O. (ed.). 2002. Fresh-cut fruit and vegetables: Science, technology, and market. CRC Press, Boca Raton, Fla.

Lange, D.L. 2000. New film technologies for horticultural products. HortTechnology 10: $487-490$.

Laties, G.G. 1995. Franklin Kidd, Charles West and F.F. Blackman: The start of modern postharvest physiology. Postharv. Biol. Technol. 5:1-10.

Lurie, S. 1998. Postharvest heat treatments of horticultural crops. Hort. Rev. 22:91-121.

Lürssen, K., K. Naumann, and R. Schroder. 1979. 1-Aminocyclopropane-1-carboxylic acid: An intermediate of ethylene biosynthesis in higher plants. Z. Pflanzenphysiol. 92:285-294.

Mattheis, J.P. and J.K. Fellman. 1999. Preharvest factors influencing flavor of fresh fruit and vegetables. Postharv. Biol. Technol. 15:227-232.

Mattoo, A.K. and A.K. Handa. 2001. Postharvest science toward the third millennium. Acta Hort. 553:761-767.

Mitcham, E.J. 2003. Controlled atmospheres for insect and mite control in perishable commodities. Acta Hort. 600:137-142.

Mrema, G.C. and R.S. Rolle. 2002. Status of the postharvest sector and its contribution to agricultural development and economic growth, p. 13-20, In: Proc. 9th JIRCAS Intl. Symp. 2002. Value-addition to agricultural products. Ibaraki, Japan.

National Academy of Sciences. 1978. Postharvest food losses in developing countries. Natl. Acad. Sci., Wash., D.C.

Nell, T.A. and M.S. Reid. 2000. Flower and plant care Soc. Amer. Florists, Alex., Va.

Paull, R.E. and J.W. Armstrong (eds.). 1994. Insect pests and fresh horticultural products: Treatments and responses. CAB Intl., Wallingford, U.K.

Paull, R.E. and N.J. Chen. 2000. Heat treatments and fruit ripening. Postharv. Biol. Technol. 21:21-37

Perkins-Veazie, P. and J.K. Collins. 2001. Contributions of nonvolatile phytochemicals to nutrition and flavor. HortTechnology 11:539-546.

Prior, R.L. and G. Cao. 2000. Antioxidant phytochemicals in fruit and vegetables: diet and health implications. HortScience 35:588-592.

Reid, M.S. 1995. Ethylene in plant growth, development, and senescence, p. 486-508, In: P.J. Davies (ed.). Plant hormones, 2nd ed. Kluwer Academic Publ., Dordrecht.

Ryall, A.L. and W.J. Lipton. 1979. Handling, transportation and storage of fruit and vegetables. vol. 1. Vegetables and melons. 2nd ed. AVI Publ. Co., Westport, Conn.

Ryall, A.L. and W.T. Pentzer. 1982. Handling, transportation and storage of fruit and vegetables. vol. 2. Fruit and tree nuts. 2nd ed. AVI Publ. Co., Westport, Conn

Romani, R.J. 1991. a perspective on postharvest physiology and biochemistry. HortScience 26:1257-1261

Saltveit, M.E. 2000. Discovery of chilling injury, p. 423-448, in: S.D. Kung and S.F. Yang (eds.). Discoveries in plant biology. Volume 3. World Scientific, Singapore.

Saltveit, M.E., S.F. Yang, and W.T. Kim. 1998. History of the discovery of ethylene as a plant growth substance, p. 47-70, in: S.D. Kung and S.F. Yang (eds.). Discoveries in plant biology. vol. 1. World Scientific, Singapore.

Seymour, G.B., J.E. Taylor, and G.A. Tucker (eds.). 1993. Biochemistry of fruit ripening. Chapman and Hall, London.

Sharp, J.L. and G.J. Hallman (eds.). 1994. Quarantine treatments for pests of food plants. Westview Press, Boulder, Colo.

Sharples, R.O. 1990. Future directions for horticultural postharvest technology. Posthar. News Info. 1:191-194.

Shewfelt, R.L. and S.E. Prussia (eds.). 1993. Postharvest handling: A systems approach. Academic Press, San Diego.

Sisler, E.C. and S.M. Blankenship. Mary 21, 1996. Methods of counteracting an ethylene response in plants. U.S. Patent No. 5,518,988

Sommer, N.F. 1989. Manipulating the postharvest environment to enhance or maintain resistance. Phytopathology 79:1377-1380.

Thompson, A.K. 1996. Postharvest technology of fruit and vegetables. Blackwell Science Ltd, Oxford, U.K.

Thompson, J.F., F.G. Mitchell, T.R. Rumsey, R.F. Kasmire, and C.H. Crisosto. 1998 Commercial cooling of fruit, vegetables, and flowers. Publ. 21567. Univ. Calif. Div. Agr. Nat. Resour., Oakland.

Wang, C.Y. (ed.). 1990. Chilling injury of horticultural crops. CRC Press, Boca Raton, Fla

Watkins, C.B. 2000. Responses of horticultural commodities to high carbon dioxide as related to modified atmosphere packaging. HortTechnology 10:501-506.

Wills, R., B. McGlasson, D. Graham, and D. Joyce. 1998. Postharvest: An introduction to the physiology and handling of fruit, vegetables, and ornamentals. CAB Intl., Wallingford, U.K.

Wilson, C.L. and M. Wisniewski. 1989. Biological control of postharvest disease. Annu. Rev. Phytopathol. 27:425-442. 